\title{
REYNOLDS DIFFERENTIAL EQUATION SINGULARITY USING PROCESSES OF SMALL STRAINING WITH LUBRICATION
}

\author{
REYNOLDSOVA DIFERENCIALNA ENAČBA PRI PROCESIH \\ MAJHNE DEFORMACIJE Z MAZANJEM
}

\author{
Dušan Ćurčija $^{1}$, Franc Vodopivec ${ }^{2}$, Ilija Mamuzić ${ }^{1}$ \\ ${ }^{1}$ Croatian Metallurgical Society, Berislavićeva 6, Zagreb, Croatia \\ 2Institute of Metals and Technology, Lepi pot 11, 1000 Ljubljana, Slovenia \\ ilija.mamuzić@public.carnet.hr
}

Prejem rokopisa - received: 2014-02-01; sprejem za objavo - accepted for publication: 2014-09-03

doi: $10.17222 /$ mit. 2014.025

\begin{abstract}
Frequently, simplified partial differential equations include transcendental functions with analytical solutions based on a singularity. Such solutions are characteristic for numerical analyses with strong Solvers and several programs singularities in the processes of dressing rolling mills with lubrication. The devised dynamical model includes the variability of the gripping angle and of the rolls radius in a section of continuous rolling. Below the real lubricant layer, in the analysis two apparent lubricant layers are presumed. The solution of the differential equation of the lubricant layer with the singularity is obtained using standard mathematical solutions for apparent lubricant layers. On the ring diagram, the transfer over the singularity shows a stronger disorder, i.e., disharmony, than the transfer over the transcendental point.

Keywords: Reynolds differential equation, singularity, dressing rolling mill, lubrication, geometrical centre

Pogosto poenostavljene diferencialne enačbe vključujejo transcendentne funkcije $\mathrm{z}$ analitičnimi rešitvami na podlagi singularne točke. Take rešitve so značilne za numerične analize $\mathrm{z}$ zmogljivimi reševalci in več singularnimi točkami $\mathrm{v}$ programih pri procesih dresirnih valjarn $\mathrm{z}$ mazanjem. Predlagan dinamičen model vključuje različnost prijemnega kota in premera valjev na delu kontinuirne valjalne proge. Pod realno plastjo maziva sta $\mathrm{v}$ analizi predpostavljeni dve navidezni plasti maziva. Rešitev diferencialne enačbe plasti maziva s točko singularnosti je dosežena z uporabo standardnih matematičnih metod za navidezni plasti maziva. Na krožnem diagramu prenos preko singularnosti pokaže večji nered oziroma disharmonijo, kot je prenos preko transcendentne točke.

Ključne besede: Reynoldsova diferencialna enačba, točka singularnosti, dresirna valjarna, mazanje, geometrična sredina
\end{abstract}

\section{INTRODUCTION}

The Reynolds ${ }^{1}$ differential equation ${ }^{2,3}$ is used for the analysis of the processes of the lubricated low reduction of metals (dressing, cold rolling and drawing) and a simplified equation is used ${ }^{4,5}$ :

$$
\frac{\mathrm{d} p}{\mathrm{~d} x}=\frac{6 \cdot \mu\left(v_{0}+v_{\mathrm{R}}\right)}{\varepsilon^{2}(x)}-\frac{12 \cdot \mu \cdot Q}{\varepsilon^{2}(x)}
$$

The approximate solution using the transcendent equation is:

$$
\begin{gathered}
A=\frac{-\alpha}{2 \varepsilon_{0} \cdot \psi}+\left(\frac{\Omega}{R \cdot \psi \cdot \xi^{0.5}}\right)+\frac{3 \alpha}{2 R \cdot \psi^{2}}-\left(\frac{3 \varepsilon_{0} \cdot \Omega}{2 R^{2} \cdot \psi^{2} \cdot \xi^{0.5}}\right) \\
\Omega=\ln \left(\frac{-\alpha-\xi^{0.5}}{-\alpha+\xi^{0.5}}\right) \quad \xi=-\psi \quad \psi=\frac{2}{R} \varepsilon_{0}-\alpha^{2} \\
A=\frac{1-\exp \left(-\gamma \cdot p_{0}\right)}{6 \mu \cdot \gamma\left(v_{0}+v_{\mathrm{R}}\right)}
\end{gathered}
$$

where $A$ is a technological parameter, $R$ is the rolls radius, $\mu$ is the lubricant dynamical viscosity, $v_{0}$ and $v_{\mathrm{R}}$ are the rolling and circumferential rolls velocity, $\alpha$ is the rolling angle, $\varepsilon(x)$ is the geometry of the lubricant layer in the deformation zone, $Q$ is the lubricant consumption, $\mathrm{d} p / \mathrm{d} x$ is the axial stressing gradient $x, \varepsilon_{0}$ is the thickness of the lubricant layer of the entry section of the deformation zone, $\gamma$ is the piezo-coefficient of the lubricant viscosity and $p_{0}$ is the rolling pressure.

The entry roll in Section I has the radius $R_{1}$, the gripping angle $\alpha_{1}$ and forms a lubricant layer with the thickness $\varepsilon_{1}$ (Figure 1). The exchange parameter $\omega$ in

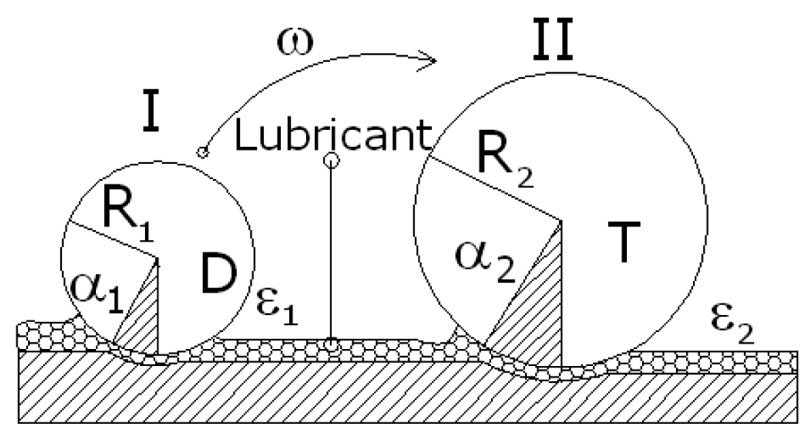

$\mathrm{D}=$ Singular point $T=$ Transcedent point

Figure 1: Scheme of the calculation of lubricant layer between two rolling stands. The entry roll I joins in the singularity, i.e., the transcedency point.

Slika 1: Shema izračuna plasti maziva med dvema valjalnima ogrodjema. Vstopni valj I doseže singularno točko oz. transcendentno točko. 
Section II changes these parameters, either as: $R_{2}=\omega^{3}$. $R_{1}, \alpha_{2}=\alpha_{1} / \omega$ or $R_{2}=R_{1} / \omega^{3}, \alpha_{2}=\alpha_{1} \cdot \omega$

The exit lubricant layer thickness $\varepsilon_{2}$ is calculated using the Solver solution of the transcendent Equation (2) and it is confirmed with a Monte Carlo numerical integration of Equation (1).

\section{NUMERICAL ANALYSIS OF THE SINGULA- RITY $D$ AND THE TRANSCENDENT POINT $T$}

As a special case of the solution of the transcendent Equation (2) is the singularity solution acceptable for dressing processes. This solution ${ }^{2,6}$ is:

$$
\varepsilon_{0}^{*}=\frac{1}{2} R \dot{\alpha}^{2} \quad \dot{\alpha}=\sqrt[3]{\frac{8}{15 R \cdot A}}
$$

Figure 2 shows the occurrence of the singularity in the dressing process with respect to the lubricant-layer thickness and the gripping angle. With respect to the singularity, the transcendent point $T$ is situated on the right-hand side.

The singularity creates a vicinity of unpredictable behaviour and the numerical analysis is spread around the singularity. The determinant (5) was used for the analysis:

$$
\left[\begin{array}{cc}
\varepsilon_{0}^{*} & \varepsilon_{0}^{\mathrm{T}} \\
\varepsilon_{0}^{\mathrm{MS}} & \varepsilon_{0}^{\mathrm{MT}}
\end{array}\right]
$$

where $\varepsilon_{0}^{*}$ is the thickness of the lubricant layer for $\dot{\alpha}, \varepsilon_{0}^{\mathrm{MS}}$ is the thickness of lubricant layer according to the Mizuno-Grudev equation for $\alpha^{*}, \varepsilon_{0}^{\mathrm{T}}$ is the thickness of the lubricant layer according to the transcendent Eq. (2) and $\varepsilon_{0}^{\mathrm{MT}}$ is the thickness of the lubricant layer according to the Mizuno-Grudev ${ }^{6}$ equation $\alpha=\alpha^{*} / \varpi$ for $\alpha=\alpha^{*} / \omega$.

If the singularity is at the interaction of two points, the value of the determinant (5) tends to zero. In the absence of a singularity between the initial and the aimed for point, the value of the determinant (5) is zero. This allows us to describe all the aimed for points' values without a singularity using:

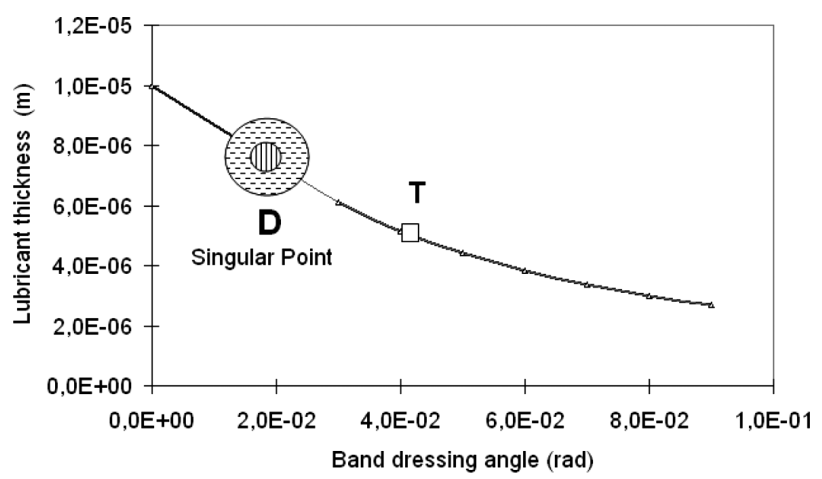

Figure 2: Vicinity of the singularity (singular point) $D\left(\dot{\alpha} ; \varepsilon_{0}^{*}\right)$ and the transcendent point $T$

Slika 2: Bližina singularne točke $D\left(\dot{\alpha} ; \varepsilon_{0}^{*}\right)$ in transcendentne točke $T$

$$
\varepsilon_{0}^{\text {Target }}=\frac{R \cdot \sqrt[3]{\left(\frac{8}{15 R \cdot A}\right)^{2}}}{2 \omega}
$$

where $\omega$ is a proportionality constant in the technical signification equal to the deformation degree. In the analysis, the apparent lubricant layer $\varepsilon_{0}$ (column $J$ ) is divided by the aimed analysis into two pseudo layers (columns $H$ and $I$ in Tables 1 and 2).

\section{SOLVER CALCULATION USING EQUATIONS (2) AND (6) WITH THE INITIAL ON THE SINGULARITY}

The results of calculations using the Solver (MathCAD, EXCEL) after the commutation law of multiplication for the condition of the technological process are listed in Table 1. With respect to the commutation law of multiplication, the external ring $J$ is the product of the inner two rings $H$ and $I$. The imagined is the rolling line with rolling 10 cages with deformation degrees varying from cage to cage. The results of the calculations are listed in Table 2 for increasing values of $\pi$.

The constructive coefficient of transfer between two rolling stands is $\alpha \cdot R=0.22145 \cdot \omega^{2}$.

Table 1: Solver calculations for Eq. (2) for three singularity rings. The variability of $\omega$ influences the variability of the clutch angle $\alpha$ and the rolls radius $R$.

Tabela 1: Izračuni enačbe (2) z uporabo reševalca za tri singularne obroče. Variabilnost $\omega$ vpliva na variabilnost prijemnega kota $\alpha$ in polmera valjev $R$.

\begin{tabular}{|c|c|c|c|}
\hline$\omega=2.2$ & $H$ & $I$ & $J$ \\
\hline 2 & $5.6881486648 \mathrm{E}-05$ & $4.3089901167 \mathrm{E}-01$ & $2.4510176379 \mathrm{E}-05$ \\
\hline 2.2 & $5.6754502094 \mathrm{E}-05$ & $4.7504943260 \mathrm{E}-01$ & $2.6961194017 \mathrm{E}-05$ \\
\hline 2.22 & $5.2837299927 \mathrm{E}-05$ & $5.1490700355 \mathrm{E}-01$ & $2.7206295781 \mathrm{E}-05$ \\
\hline 2.222 & $6.2070776615 \mathrm{E}-05$ & $4.3870573952 \mathrm{E}-01$ & $2.7230805957 \mathrm{E}-05$ \\
\hline 2.2222 & $5.4395165663 \mathrm{E}-05$ & $5.4219876699 \mathrm{E}-01$ & $2.9492991753 \mathrm{E}-05$ \\
\hline 2.22222 & $5.9160153196 \mathrm{E}-05$ & $4.6033521899 \mathrm{E}-01$ & $2.7233502077 \mathrm{E}-05$ \\
\hline 2.22222222 & $5.2737233458 \mathrm{E}-05$ & $5.1640036463 \mathrm{E}-01$ & $2.7233526587 \mathrm{E}-05$ \\
\hline 2.2222222 & $5.4753146188 \mathrm{E}-05$ & $4.9738747779 \mathrm{E}-01$ & $2.7233529284 \mathrm{E}-05$ \\
\hline 2.22222222 & $4.7791846331 \mathrm{E}-05$ & $5.6983630888 \mathrm{E}-01$ & $2.7233529308 \mathrm{E}-05$ \\
\hline & $5.6585859142 \mathrm{E}-05$ & $4.8127800343 \mathrm{E}-01$ & $2.7233529310 \mathrm{E}-05$ \\
\hline
\end{tabular}


Table 2: Solver calculations for three singularity rings using Eq. (2)

Tabela 2: Izračuni z uporabo reševalca za tri obroče singularnosti z enačbo (2)

\begin{tabular}{|c|c|c|c|}
\hline$\omega=\pi$ & $H$ & $I$ & $J$ \\
\hline 3 & $9.0652411487 \mathrm{E}-01$ & $4.0556839290 \mathrm{E}-05$ & $3.6765752839 \mathrm{E}-05$ \\
\hline 3.1 & $7.2525287463 \mathrm{E}-01$ & $5.2383491694 \mathrm{E}-05$ & $3.7991277934 \mathrm{E}-05$ \\
\hline 3.14 & $9.9122718480 \mathrm{E}-01$ & $3.8822066788 \mathrm{E}-05$ & $3.8481487970 \mathrm{E}-05$ \\
\hline 3.141 & $6.2041700114 \mathrm{E}-01$ & $6.2044951242 \mathrm{E}-05$ & $3.8493742586 \mathrm{E}-05$ \\
\hline 3.1415 & $9.7002625173 \mathrm{E}-01$ & $3.9689514361 \mathrm{E}-05$ & $3.8499870849 \mathrm{E}-05$ \\
\hline 3.14159 & $8.4111868525 \mathrm{E}-01$ & $4.5773532910 \mathrm{E}-05$ & $3.8500973821 \mathrm{E}-05$ \\
\hline 3.141592 & $8.2952986160 \mathrm{E}-01$ & $4.6413034797 \mathrm{E}-05$ & $3.8500998332 \mathrm{E}-05$ \\
\hline 3.1415926 & $1.0885265884 \mathrm{E}+00$ & $3.5369834871 \mathrm{E}-05$ & $3.8501005684 \mathrm{E}-05$ \\
\hline 3.14159265 & $8.8297139988 \mathrm{E}-01$ & $4.3603910956 \mathrm{E}-05$ & $3.8501006297 \mathrm{E}-05$ \\
\hline 3.141592654 & $8.0201286093 \mathrm{E}-01$ & $4.8005472508 \mathrm{E}-05$ & $3.8501006346 \mathrm{E}-05$ \\
\hline
\end{tabular}

Figure 3 has a mark for the turn of the apparent lubricant rings $H$ and $I$ with the singularity as the initial point with respect to the fictive outer lubricant layer for the cage rolling for ten cages in the rolling line.

The transfer in Figure $\mathbf{4}$ also indicates the discordance of the inner two rings as in Figure 3, where the transfer was achieved using the Solver.

\section{APPARENT LUBRICANT LAYERS $H$ AND $I$}

The Solver solution of the transcendent equation, the apparent layers $H$ and $I$ may have different results for an equal degree of deformation, as listed in Table 3. The value of the lubricant layer $J=H * I$ is equal, as also shown by the solution of Eq. (1).

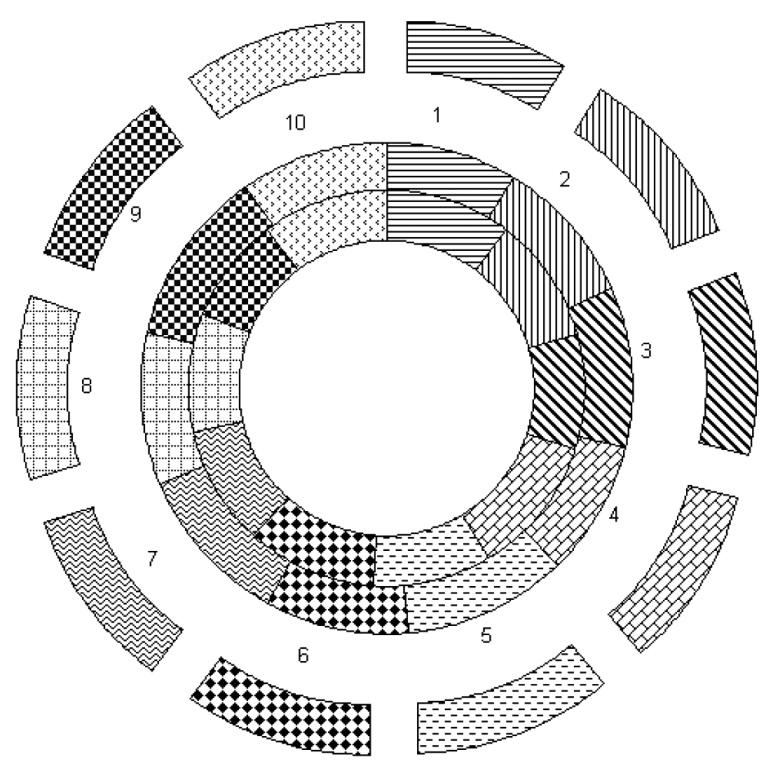

Figure 3: Aimed for transcendent point from the singularity after the Solver and Eq. (2) with: $\omega=2.222222222, \alpha=1.107262798 / \omega, R=$ $0.2 \cdot \omega^{3}, A=1965512 \mathrm{~m}^{-1}, R=0.2 \mathrm{~m}, \alpha=1.107402627 \mathrm{rad}, \mu \cdot \gamma=$ $5.232 \cdot 10^{-9}$ and $p_{0} \cdot \gamma=4.36 \mathrm{~s}$

Slika 3: Ciljana točka transcendentnosti na podlagi singularnosti, izračunane z uporabo reševalca in enačbe (2) z: $\omega=2,222222222, \alpha=$ $1,107262798 / \omega, R=0,2 \cdot \omega^{3}, A=1965512 \mathrm{~m}^{-1}, R=0,2 \mathrm{~m}, \alpha=$ $1,107402627 \mathrm{rad}, \mu \cdot \gamma=5,232 \cdot 10^{-9}$ in $p_{0} \cdot \gamma=4,36 \mathrm{~s}$
The constructive transfer coefficient between two rolling cages is $\alpha \cdot R=0.22145 / \omega^{2}$.

The data in Table 3 are depicted in Figure 5.

The results of the investigation of the columns $H$ and $I$ are listed in Table 4. The geometrical average of the column $J$ is obtained using the apparent lubricant layers $K$ and $I$. The relation of the column $J$ and the apparent lubricant columns $K$ and $I$ are also supported by the standard mathematical averages: arithmetic, harmonic, geometric, quadratic, etc.

Although having an equal value to the external, i.e., third ring $J$, the lower apparent rings $H$ and $I$ are in disharmony with the external ring, and only with values for $i=1$ is the harmony achieved. The second series $i=2$ creates the inversion of the two internal rings, while the series $i=3$ supports the turn, i.e., with respect to the external ring $J$. As explained already, this is supported by

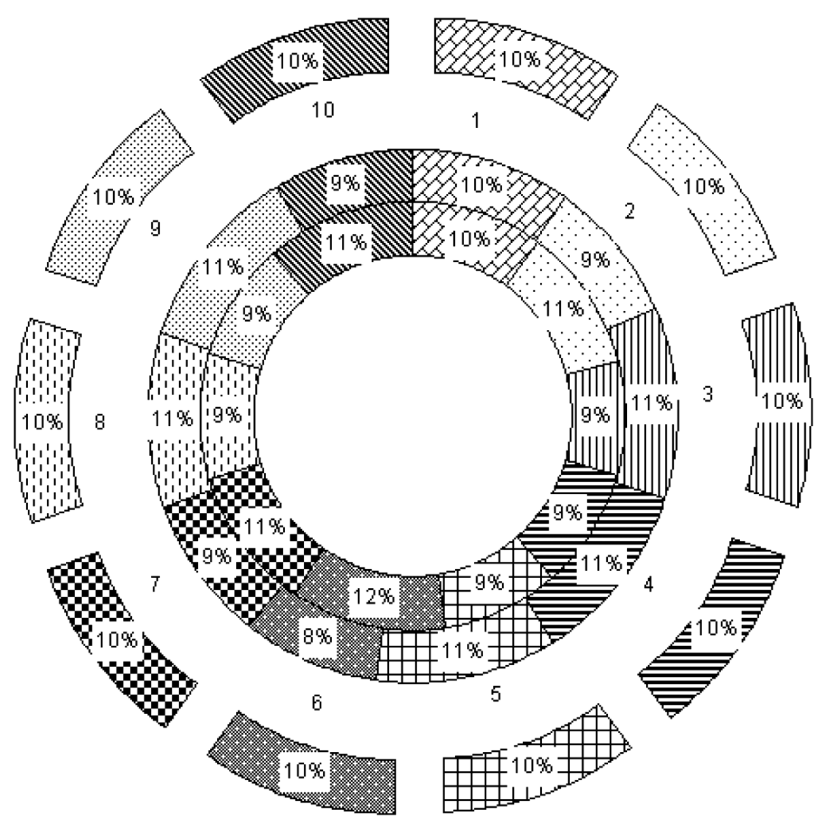

Figure 4: Transfer of similarity for the singularity to the transcendent point using Eq. (6)

Slika 4: Prenos podobnosti s točke singularnosti na točko transcendentnosti $\mathrm{z}$ enačbo (6) 


\section{D. ĆURČIJA et al.: REYNOLDS DIFFERENTIAL EQUATION SINGULARITY USING PROCESSES ...}

Table 3: Different values in the columns $H$ and $I$ for the equal degree of deformation $\omega=3$

Tabela 3: Različne vrednosti v kolonah $H$ in $I$ za enako stopnjo deformacije $\omega=3$

\begin{tabular}{|c|c|c|c|c|}
\hline$i$ & $\omega=3.0$ & $H$ & $I$ & $J$ \\
\hline 1 & 3 & $3.6080500075 \mathrm{E}-05$ & $1.1321986636 \mathrm{E}-01$ & $4.0850293967 \mathrm{E}-06$ \\
\hline 2 & 3 & $3.6684996110 \mathrm{E}-05$ & $1.1135422733 \mathrm{E}-01$ & $4.0850293964 \mathrm{E}-06$ \\
\hline 3 & 3 & $4.4999094308 \mathrm{E}-05$ & $9.0780258123 \mathrm{E}-02$ & $4.0850293966 \mathrm{E}-06$ \\
\hline 4 & 3 & $4.5445189361 \mathrm{E}-05$ & $8.9889148972 \mathrm{E}-02$ & $4.0850293965 \mathrm{E}-06$ \\
\hline 5 & 3 & $5.1287540856 \mathrm{E}-05$ & $7.9649547013 \mathrm{E}-02$ & $4.0850293966 \mathrm{E}-06$ \\
\hline 6 & 3 & $6.1373811833 \mathrm{E}-05$ & $6.6559812314 \mathrm{E}-02$ & $4.0850293966 \mathrm{E}-06$ \\
\hline
\end{tabular}

Table 4: Geometrival averages of columns $H$ and $I$ in interval form Tabela 4: Geometrična povprečja kolon $H$ in $I$ v intervalni obliki

\begin{tabular}{|c|c|c|c|}
\hline$\Delta i$ & $H$ & $I$ & $J$ \\
\hline$i=1$ to 6 & $4.5193358310 \mathrm{E}-05$ & $9.0390038477 \mathrm{E}-02$ & $4.0850293966 \mathrm{E}-06$ \\
\hline$i=2$ to 6 & $4.5232311633 \mathrm{E}-05$ & $9.0312196062 \mathrm{E}-02$ & $4.0850293966 \mathrm{E}-06$ \\
\hline$i=3$ to 6 & $4.3833687801 \mathrm{E}-05$ & $9.3193833361 \mathrm{E}-02$ & $4.0850293966 \mathrm{E}-06$ \\
\hline$i=4$ to 6 & $3.9181673469 \mathrm{E}-05$ & $1.0425867593 \mathrm{E}-01$ & $4.0850293966 \mathrm{E}-06$ \\
\hline
\end{tabular}

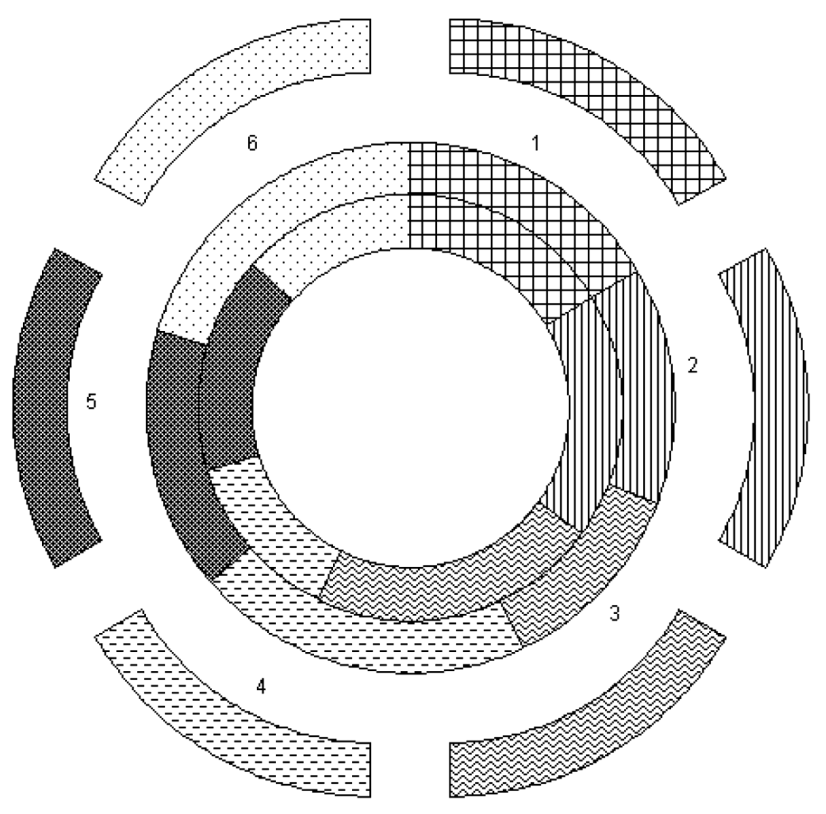

Figure 5: Ring diagram of Table 3 calculated using the Solver from the initial singularity for two rolling stands

Slika 5: Krožni diagram tabele 3, izračunan z reševalcem od začetne točke singularnosti za dve valjalni ogrodji

the mathematical average and the law of commutation of the hyperbolic multiplication.

Further, the numbers in Table 4 show that for the values of columns $J(J=H * I)$ :

$$
G=A \cdot H
$$

$G$ is the geometrical average for column $J$

$A$ is the arithmetic average for column $I$

$H$ is the harmonic average for column $H$.

The numbers in column $J$, Table 3 could also be obtained with the opposite values of the apparent lubricant layers $K$ and $I$, e.g.:
$G=\frac{H_{6}+I_{4}}{2} \cdot \frac{2}{\left(1 / H_{4}\right)+\left(1 / I_{6}\right)}=4.0850293966 E-06$

The connection between the apparent layers is supported by the algebraic opposite identity of several possible and with respect to Table $\mathbf{3}$, on the hyperbole for the first step it is:

$$
\begin{aligned}
& \sqrt[3]{\frac{\left(H_{i+1}\right)^{3}+\left(I_{i}\right)^{3}}{2}}+\sqrt[3]{\frac{\left(H_{i+1}\right)^{3}+\left(I_{i+1}\right)^{3}}{2}}= \\
& =2 \sqrt[3]{\frac{\left(H_{i+1}\right)^{3}+\left(I_{i+2}\right)^{3}}{2}}
\end{aligned}
$$

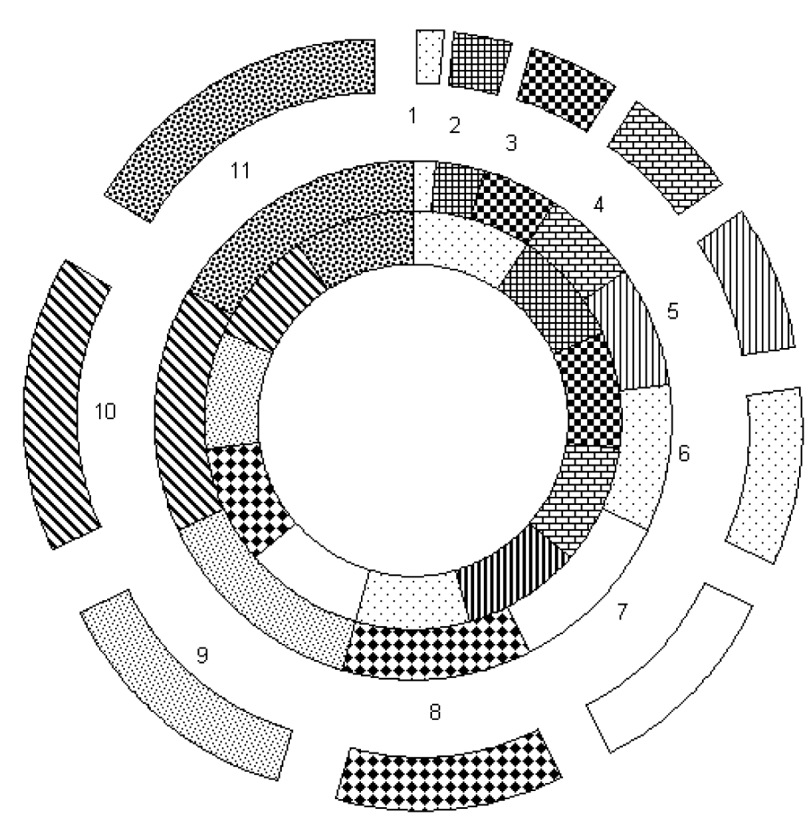

Figure 6: Disorder on the transcendent point by a large degree of metal deformation using the initial singularity calculated with the Solver

Slika 6: Nered na točki singularnosti pri veliki stopnji deformacije za začetno točko singularnosti, izračunano $\mathrm{z}$ reševalcem 
D. ĆURČIJA et al.: REYNOLDS DIFFERENTIAL EQUATION SINGULARITY USING PROCESSES ...

Table 5: Solver calculation for large metal deformation from the singularity to the transcendent point

Tabela 5: Izračuni z uporabo reševalca za velike deformacije od točke singularnosti do točke transcendentnosti

\begin{tabular}{|c|c|c|c|}
\hline & $H$ & $I$ & $J$ \\
\hline 2 & $4.9140375541 \mathrm{E}-01$ & $1.4369767894 \mathrm{E}-05$ & $7.0613579075 \mathrm{E}-06$ \\
\hline 3 & $4.9140375543 \mathrm{E}-01$ & $2.8739535788 \mathrm{E}-05$ & $1.4122715816 \mathrm{E}-05$ \\
\hline 4 & $4.9140375554 \mathrm{E}-01$ & $4.3109303672 \mathrm{E}-05$ & $2.1184073723 \mathrm{E}-05$ \\
\hline 5 & $4.9140375543 \mathrm{E}-01$ & $5.7479071576 \mathrm{E}-05$ & $2.8245431631 \mathrm{E}-05$ \\
\hline 6 & $4.9140375544 \mathrm{E}-01$ & $7.1848839468 \mathrm{E}-05$ & $3.5306789539 \mathrm{E}-05$ \\
\hline 7 & $4.9140375585 \mathrm{E}-01$ & $8.6218607289 \mathrm{E}-05$ & $4.2368147446 \mathrm{E}-05$ \\
\hline 8 & $4.9140375543 \mathrm{E}-01$ & $1.0058837526 \mathrm{E}-04$ & $4.9429505355 \mathrm{E}-05$ \\
\hline 9 & $4.9140375543 \mathrm{E}-01$ & $1.1495814315 \mathrm{E}-04$ & $5.6490863261 \mathrm{E}-05$ \\
\hline 10 & $4.9140375543 \mathrm{E}-01$ & $1.2932791105 \mathrm{E}-04$ & $6.3552221172 \mathrm{E}-05$ \\
\hline 11 & $4.9140375543 \mathrm{E}-01$ & $1.4369767894 \mathrm{E}-04$ & $7.0613579078 \mathrm{E}-05$ \\
\hline
\end{tabular}

The singularity coexists with two apparent lubricant layers, which are in the ring diagram incongruous with respect to the external apparent lubricant layer $J$ and the disharmony i.e., the disorder may be obtained. The internal apparent lubricant rings rotate with respect to the external fixed ring and neither are congruent.

\section{LARGE METAL DEFORMATION}

The calculation results are listed in Table 5. By transferring the similarity from cage to cage, the deformation coefficient varies strongly.

In Figure $\mathbf{6}$ the data from Table $\mathbf{5}$ are depicted as a ring diagram. The great rings disorder by the transfer of disharmony on the outer ring $J$ was calculated using the transcendent Eq. (2). The results of this calculation ${ }^{7}$ were confirmed by a numerical integration ${ }^{7}$ Monte-Carlo of Eq. (1). The apparent column $H$ is constant by rolling on a line with 11 rolling cages.

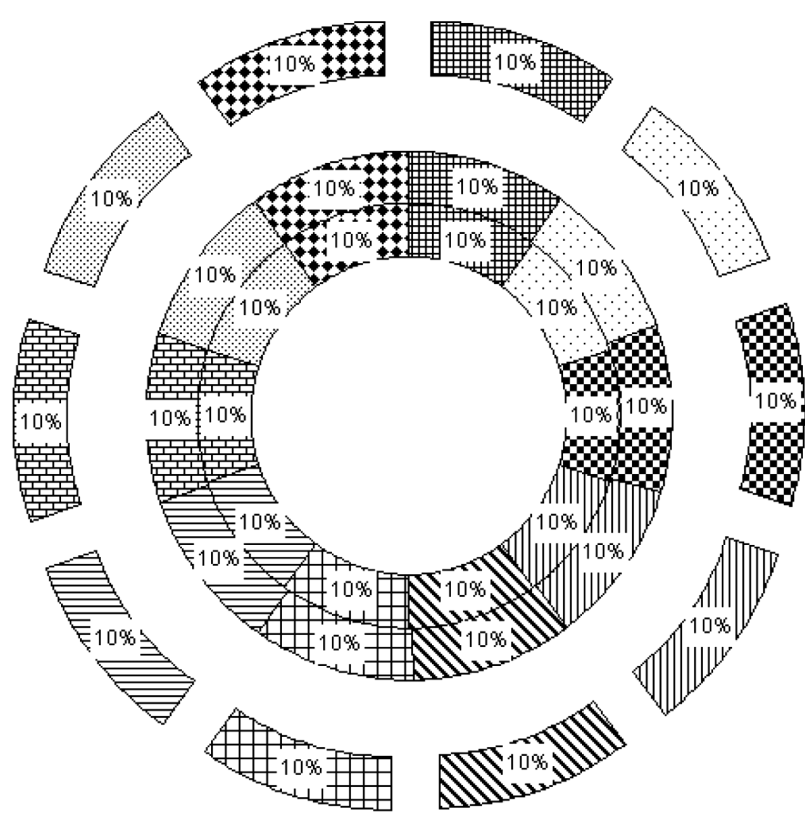

Figure 7: Example of rhythmics by ten cages Slika 7: Primer ritmičnosti za deset ogrodij

\section{TRANSFER TRANSCENDENT TO TRANSCENDENT POINT}

The initial roll in Figure $\mathbf{1}$ is on the transcendent point $T$ in Figure 2. The Solver calculation of the lubricant layer between two connected cages shows great stability and rhythmics (Figure 7).

The apparent lubricant layers $K$ and $I$ turn within and unrelated to the external lubricant layer $J$. The congruency of all three rings is achieved without discordant inversions in rings $H$ and $I$.

The transfer is:

$$
R_{i+1}=\omega^{3} R_{i} \quad \alpha_{i+1}=\alpha_{i} / \omega \quad \alpha_{i}=3.141592654
$$

Using $\omega=1$ no transfer of similarity coefficient should occur as both rolls in Figure $\mathbf{1}$ are in the same position and no metal deformation occurs on the dressing line.

\section{CONCLUSION}

The mixing and penetration of the layers in the $H$ and $I$ rings by calculation using Eq. (6) are the evaluation of the stability of technological procedure of rolling on continuous lines with different degrees of deformation $\omega$. The mixing is diminished essentially by Solver calculations, although the layer inversion could be obtained, also. Besides inversion, according to law commutation of multiplication, the layers are inclined to rotation at the singularity with respect to the outer layers. For proper use of the Solver program, experience is necessary. The apparent layers $H$ and $I$ are connected to the column $J$ and the related geometrical average after Eq. (7) verified by numerical integration. It was shown that the data in column $J$ in Table 4 could also be calculated using Eq. (8), which was not generalised. Eq. (9) is a possible connection of apparent lubricant layers $K$ and $I$. The transcendent point shows the marked order for the lubricant layer better than the singularity.

The results of the calculation of lubricant layer using the Reynolds equation agree well with experimental results for the processes of dressing of bands and cold 


\section{D. ĆURČIJA et al.: REYNOLDS DIFFERENTIAL EQUATION SINGULARITY USING PROCESSES ...}

tube drawing ${ }^{8,9}$ and by investigations of the contact friction $^{10}$.

\section{Acknowledgements}

The authors are indebted to prof. F. Vodopivec for useful comments and the Croatian-to-English translation of the manuscript.

\section{REFERENCES}

${ }^{1}$ D. Ćurčija, F. Vodopivec, I. Mamuzić, Mater. Tehnol., 47 (2013) 1, 53-57

${ }^{2}$ D. Ćurčija, I. Mamuzić, Mater. Tehnol., 41 (2007) 1, 21-27
${ }^{3}$ D. Ćurčija, I. Mamuzić, Mater. Tehnol., 42 (2008) 2, 59-63

${ }^{4}$ D. Ćurčija, I. Mamuzić, Metalurgija, 44 (2005) 3, 221-226

${ }^{5}$ D. Ćurčija, I. Mamuzić, Metalurgija, 44 (2005) 4, 295-300

${ }^{6}$ D. Ćurčija, Mater. Tehnol., 37 (2003) 5, 237-250

${ }^{7}$ M. I. Sobol, Die Monte Carlo Methode, Ver. H. Deutsch, Frankfurt a. Main 1986

${ }^{8}$ O. P. Maksimenko, A. A. Semenča, Issledovanie kontaktno-gidrodinamičeskoj smazki pri prokatke, Sučasni problemi metallurgii, 8 (2005), 99-103

${ }^{9}$ M. R. Jensen, L. Olovsson, J. Danckert, Numerical model for the oil pressure distribution in the hydromechanical deep drawing process, J. Mater. Process. Techn., 103 (2000) 1, 74-79, doi:10.1016/S09240136(00)00421-0

${ }^{10}$ P. Heyer, J. Läuger, Correlation between friction and flow of lubricating greases in new tribometer device, Lubrication Science, 21 (2009) 7, 253-268, doi:10.1002/ls.88 